\title{
THE USE OF "EMPIRICAL EVIDENCE?" IN THE SPANISH CRIMINAL LEGISLATIVE PROCESS FROM 1992-1995 TO THE PRESENT ${ }^{1}$
}

\section{Samuel Rodríguez Ferrández}

Associate Professor of Criminal Law Centre of Criminological Studies (University of Murcia)

Correspondence: samuel.rodriguez@um.es

Received: 16.04.2020

Accepted: 04.05.2020

\section{How to cite this paper}

Rodríguez Fernández, S. (2020). The use of "empirical evidence?" in the spanish criminal legislative process from 1992-1995 to the present. Spanish Journal of Legislative Studies. (2), p.1-27. DOI: https://doi.org/10.21134/sjls.vi2.1288 
THE USE OF “EMPIRICAL EVIDENCE?" IN THE SPANISH CRIMINAL LEGISLATIVE PROCESS FROM 1992-1995 TO THE PRESENT.

Samuel Rodríguez Fernández

\section{SUMMARY}

1. Introduction. 2. "Empirical evidence?" in the Spanish criminal legislative process 3. Conclusions. 


\section{INTRODUCTION.}

The purpose of this paper is to analyse the introductory texts of the various Organic Laws that have shaped the text of our current Criminal Code over the last 25 years. Recourse to these introductory texts (whether they are Explanations of Reasons or Preambles, as we shall see below) is obligatory -at least as a first source of information- if we wish to know which have been throughout this period the reasons given by the different criminal legislators for undertaking the multiple reforms that have been approved and came into force. As a methodological alternative, we could have resorted to the reports that the different governments have been sending to Parliament to justify the initial bills of all the Organic Laws analysed, in order to appreciate a perhaps more "pure" version of the reasons of the legislative promoter; however, apart from the fact that the information contained in both types of justification-explanation text usually coincides in essence, that of the Organic Laws offers more up-to-date information that is in line with the final text of the approved regulation and, above all, it is much easier to access it, without having to make an individual request for the documentation attached to each bill to the "Office of Documentation, Library and Archives" of the Congress of Deputies.

In any case, the true and fundamental purpose of this analysis is to extract from such texts the references made by the various criminal le- gislators to the use of information that could be considered, even indirectly, as evidence from a scientific point of view. However, whether or not they are considered as such will differ from the conclusions of the paper.

Well, the first question to be addressed without further delay, as it is decisive for the future of this analysis, is to define what we can understand by "empirical evidence". Thus, we can conceptualize as such any information of reality acquired through the scientific method, using observation, direct experience or experimentation, thus allowing the hypotheses that are formulated as a result of it to be verified or refuted by other researchers.

Defined in this way, the purpose of this paper is to identify which "empirical evidence" different legislators have argued to use throughout all the criminal laws that have given rise to the text of our current Criminal Code. For this purpose, it has been sufficient to read the different Explanatory Memoranda and Preambles of all these laws. In fact, in some of them they have used "Explanations of Reasons" (until 2005, with a couple of specific exceptions) and in others "Preambles" (from 2007 until 2019) to refer to the content of the different reforms that these Organic Laws introduced over the years.

However, before undertaking such an individualised analysis, law by law, I believe it is convenient to clarify, even by telegraph, the main differences, at least on a theoretical level (without

\footnotetext{
${ }^{1}$ This paper has been prepared in the context of the research project entitled "Criminology, Empirical Evidence and Criminal Policy. On the incorporation of scientific data for decision-making in relation to the criminalisation of behaviour (NEXO)" (DER201786204-R), included in the State Programme for "Research, Development and Innovation geared to the Challenges of Society", within the framework of the State Plan for "Scientific and Technical Research and Innovation" 2013-2016 (Call 2017), financed by the Ministry of Economy, Industry and Competitiveness, State Secretariat for Research, Development and Innovation of the Spanish Government. ${ }^{4}$ In this regard, Putnam (2002) perfectly synthesised the ethos of this transition between paradigms in Rationality and value, stating that knowledge of facts presupposes knowledge of values, and criticising that the positivist philosophy of science in the first half of the 20th century has been largely a history of attempts to evade this issue. To put it another way, they consider preferable to retain the dogma that facts are objective, and values are subjective, and that they do
} 
much confidence that they have really been taken into account in the criminal legislative practice that we will analyse below) between a "Statement of Reasons" and a "Preamble"2. Thus, on the one hand, the "Explanatory Memorandum" has three essential objectives: to reason and gloss over the content of the rule, to play a role of political control of the executive by the legislature and to rationalise the legislative initiative. On the other hand, the "Preambles" are intended: to make a generic invocation of the reasons and objectives pursued, to play an educational or pedagogical role and to connect the past (the starting situation) with the future (the goals to be achieved).

\section{II. “EMPIRICAL EVIDENCE?” IN THE SPANISH CRIMINAL LEGISLATIVE PROCESS.}

Once this conceptual and functional distinction is established, it is time to clear up what the allusions to possible "empirical evidence" have been by our criminal legislators in each of the Organic Laws that have intervened to configure our Criminal Code over the last almost three decades.

\section{Draft Organic Law of the Criminal Code (1992) - Explanation of Rea- sons.}

In this first legislative text, which we take into consideration despite the fact that it did not end with the approval of the corresponding Organic Law due to its great wealth of arguments and because it immediately preceded the first one that was approved, the legislator alludes to circumstances that had to do with the reality of the time, such as "the change in social and cultural conditions", the "evolution of Spanish society since 1975" or the "technological and economic development", in order to justify his proposal. It is also mentioned as a document prior to taking into consideration the so-called "Moncloa Pacts", insofar as they contained a "political commitment" to "provide Spanish society with a punitive system consistent with its needs", something which the legislator made a little more specific by stating that this society "wishes to resort as little as possible to criminal prosecution".

In addition to this last statement, it is striking that the text also states that "it is absurd to threaten very long sentences which will not be served under any circumstances", and the legislator then advocates, with the utmost conviction, a limitation of the effective serving of sentences of imprisonment to twenty years and only exceptionaIly to thirty years. But it was also stated, without using any empirical basis to support such a statement, that "short custodial sentences should be avoided", proposing for this purpose not to establish any less than six months and to introduce weekend detention.

When it comes to making specific reference to the main innovations that the normative text intended to introduce into our legal system in the regulated legal-criminal institutions, there are a number of arguments of an alleged or supposed empirical nature, namely:

- With regard to the remission of penalties for work, it is said that "it has become an automatic mechanism for reducing the duration of penalties, regardless of the behaviour of the prisoner and which, understandably, is due to the

\footnotetext{
${ }^{2}$ SANTAOLALLA LÓPEZ, F., "Exposiciones de Motivos de las leyes: motivos para su eliminación”, in Revista Española de Derecho Constitucional, No. 33, 1991, p. 50
} 
excessive theoretical duration of many penalties".

- With regard to the duration of the security measures, it is proposed that they be subject to what would have been the penalty, thus "meeting" a claim that is already old in Spanish criminal practice.

- To refer to testing, it is said that it is an institution "demanded by some social sectors concerned with the problem of recovery from diversion" and that "in some countries it is regulated as an alternative possibility to criminal reaction [...] for primary offenders who commit crimes that do not exceed a certain gravity".

On abortion, it is stated that "the most recent jurisprudence of the 2 nd (Criminal) Chamber of the Supreme Court has been taken into account" when declaring the validity of the application of the state of necessity in certain cases.

In announcing the novelty of incriminating injuries to the foetus and genetic manipulations, it indicates that such behaviours "must be attacked, since, as certain experiences teach, they are not, unfortunately, unimaginable".

- With regard to the correction of certain defects in the reform carried out in 1989 on crimes against sexual freedom, reference is made to the fact that the punitive comparison between the crime of rape and that of homicide is "defended by some" and that it "places the courts under an extraordinary strain" when it comes to passing sentence with equanimity.

When it comes to the criminal protection of the secrets of legal persons, it is said that this is "in compliance with the Constitutional Court's interpretative guidelines".

When referring to the changes in crimes against honour, it is argued that "doctrinal experience has had a decisive weight, including scientific doctrine, the Supreme Court and the Constitutional Court".

When discussing crimes against the fami- ly, it is stated that "for many years now, a sector of the criminal doctrine has been calling for the creation of a Title of the Code" dedicated to the protection of this institution

- Referring to the Title on "Social-economic crimes", it explains that "the controversy over the scope and content of these crimes, which began in 1979, has not ceased over all these years", but that this "does not mean that adapting the current crimes against heritage would be sufficient to satisfy all modern political-criminal requirements". Within these crimes, which are regulated together with heritage crimes, there are many references to supposedly empirical arguments:

o Regarding crimes of seizure (theft and robbery), it is stated that its traditional formulations "have shown great flexibility and precision, and there is a doctrinal and jurisprudential elaboration on them that cannot be ignored".

o When referring to complex figures of theft, it is indicated that a "modification that had been increasingly demanded by doctrine" is introduced and that this results in the proposal of "the most rational and simple solution".

o When referring to the introduction of mopeds in the crimes of theft and robbery of motor vehicles, it is indicated that their temporary removal "was, in the opinion of many, unpunished".

o Regarding the occupation of empty houses or premises, it is said that one of its novelties is "explainable by political-criminal reasons".

o A significant number of new developments in punishable insolvencies are introduced because "the aim is to put an end to the current situation, in which the black figure for fraudulent insolvencies is enormous" due to a regulation that "does not stand up to scrutiny by comparative law".

o The introduction of the new offence of altering prices in tenders and auctions is said to be 
intended to address "corrupt practices that have led to the discrediting of public auctions" and to punish "much more frequent behaviour than that currently criminalised".

o When referring to the disappearance of the crime of usury, it is argued that "it has been accepted that the price of money is something that depends on the market and the circumstances involved" and that "deciding which interest is fair and which is reprehensible is out of the question".

o In explaining the introduction of corporate offences, it is said that a "justifying reason [...] is drawn from practical experience: the existence of a sector of the private legal system dedicated to incidents that may arise in the life or activity of companies has given rise to an unacceptable practice [jurisprudence], according to which problems of this kind do not have to be treated criminally, because they already have their own specific legal solution regime".

- Finally, in explaining the behaviour classified as the crimes of receiving and laundering money, it is explained that these are "a major political-criminal problem" and that the reform has "provided them with a more effective scope", taking into consideration "the current criminological reality, and also the international commitments assumed by Spain". In fact, it is stated, by way of example, that "it is therefore clear that the old fence, who was dedicated to buying stolen objects, is today a secondary criminological figure, although he is the almost sole protagonist of the current regulation of the matter".

- As for drug trafficking, it is said that "it is an evil whose propagation must be avoided because it is clearly criminogenic and produces social invalidity in the subjects affected".

- When explaining crimes of catastrophic risk, it is referred "the need to advance the frontier of punitive intervention by creating crimes of risk, since the tragic consequences of the material concretion of this risk, makes the mere punishment of the results through hypothetical qualifications of punishable imprudence a very poor criminal political strategy".

- $\quad$ On the subject of offences against public health relating to medicinal and food substances, it is stated that they are based on "the increase in health risk prevention policy [...] which has led to a broadening of the spectrum of risky offences, incorporating behaviour that is today incomprehensibly atypical".

- It is explained that the Title on falsehoods "has improved and expedited the technique and the political criminal capacity", in view of what are considered "two serious deficiencies": "the number of defects in the current system", and the fact that "at present [...] new technologies have produced a wide range of objects capable of collecting and storing texts".

- When referring to the suppression of the crime of improper use of noble titles, it is argued that "neither the subject requires the intervention of criminal law, nor has the current incrimination prevented this frequent, albeit irrelevant, practice".

As for the crime of concealment, the reform expressly rejects an applicable interpretation of "part of Spanish jurisprudence" when dealing with the prior agreement between the perpetrator and the accomplices.

- As regards false accusations and complaints, it is claimed that the amendment will resolve the scope of protection of the right to effective judicial protection, "a problem raised in the current Code, which, denounced by the doctrine, has begun to find a solution thanks to some decisions of the Constitutional Court".

- The classification of attempts to disrupt order in cultural or sporting events is based on "the tragic consequences which have sometimes 
resulted from this". Specifically, it is further stated that the public display of weapons is "a conduct which undoubtedly disturbs public peace but which today goes unpunished".

- And, finally, by referring to the already repealed Book III of the Criminal Code, relating to misdemeanours, the legislator does not hesitate to set out the debate on their incrimination, as follows: "The incrimination of misdemeanours has been, and continues to be, a subject of controversy between those who believe that the presence of two types of criminal offences (crimes and misdemeanours) is good, in the understanding that there are qualitatively or quantitatively small problems but that, politically and criminally, they should be problems that can be solved through criminal proceedings, and those who categorically maintain that the existence of the book of misdemeanours is in itself incompatible with the principle of minimum intervention. Those who do so maintain, not without some reason, that the acts described and punished in Book III could well be prosecuted as administrative offences and thus, moreover, more effective penalties than those currently provided for in respect of minor offences could be imposed. The same views add that, if any of the facts described in Book III were to be considered inadmissible for referral to the administrative penalty system, it would be sufficient to transfer it to Book II as the minimum form of the offence which by its nature is closest to it".

As a result of this passage, the legislator stated that "surely, the radical disappearance of all of them was excessively traumatic", so that "based on the conviction [...] that the existence of misde- meanours is residual, the Project typifies a group of misdemeanours in Book III".

\section{Organic Law 10/1995, of 23 No- vember - Explanation of Reasons.}

Paradoxically, in contrast to the wealth of arguments in the Explanation of Reasons for the previous project, which we have already said did not culminate as such in the Organic Law, the parsimony of the one that did, this one that we are analysing now, draws powerful attention. It is not in vain that QUINTERO OLIVARES recalls that "there is a broad doctrinal consensus that the 1995 text worsened the 1992 Project, which was more advanced on various issues" ${ }^{3}$. In this sense, the author explains that the technical commission presided over by VIVES ANTÓN was entrusted with "smoothing out the rough edges" with the main opposition parliamentary group "by acceding to the requests of its technicians", which was not achieved because it was the only one that did not vote in favour of the approval of the Organic Law, abstaining ${ }^{4}$. LÓPEZ GARRIDO (then deputy of Izquierda Unida) and GARCíA ARÁN hold a different viewpoint, considering that the parliamentary process allowed the "Government Code" to be changed and "substantially" improved, resulting in a "Parliament Code" with "an acceptable text, although not satisfactory in its entirety" 5 .

Be that as it may, this 1995 text begins by referring to the fact that "the Criminal Code must protect the basic values and principles of social

\footnotetext{
${ }^{3}$ QUINTERO OLIVARES, G., Pequeña historia penal de España, lustel, Madrid, 2017, p. 217.

4 QUINTERO OlIVARES, G., Pequeña... ob. cit. p. 218.

${ }^{5}$ LÓPEZ GARRIDO, D./GARCíA ARÁN, M., El Código Penal de 1995 y la voluntad del legislador. Commentary on the text and the parliamentary debate, Eurojuris, Madrid, 1996.
} 
coexistence and that "when these values and principles change, they must also change". It also refers to the fact that "the current text dates back, in what could be considered its basic nucleus, to the last century" and that the new Code confronted the antinomy between the principle of minimum intervention and "the growing need for protection in an increasingly complex society".

It is argued that "evidence such as the parliamentary discussions of 1992, the opinion of the General Council of the Judiciary, the state of jurisprudence and the opinions of scientific doctrine" have been "taken into account" in the drafting of the Law.

And then, only arguments drawn from reality or supposedly empirical are referred to when explaining two modifications:

- With regard to crimes against sexual freedom, it is stated that "under the protection of women's honesty, an intolerable situation of offence was hidden", totally eliminated by the new regulation, with regard to which the legislator considers that "moving away from tradition seems to be a good idea" when using new punitive techniques.

- As for the crime of abortion, he warns that "the Constitutional Court demanded that in the configuration of these cases [those of non-criminalization] guarantees be adopted that do not seem to belong in a Criminal Code, but rather in another type of norm", suggesting that this was the reason why they have not been regulated in all these years within the Punitive Text.

\section{Organic Law 2/1998, of 15 June - Explanation of Reasons.}

Here the central theme is street violence and it is said that "it has become one of the most relevant phenomena for citizen coexistence over the last few years". And, to justify its seriousness, he alludes to the fact that "the media and the most diverse forums for reflection and political and social debate" have confirmed this, provoking a "social impact" that "has been accentuated by the widespread sensation of impunity with which those responsible have been acting.

The "response of the democratic institutions", says the legislator, must be "multidirectional" (apart from "calm and adjusted") and, in particular, must "complete and adjust the rules regulating the action of the punitive system", adding later that "it is notorious that there are still cases in which citizens cannot meet or demonstrate freely".

It concludes that the measures contained in the reform are "the result of careful reflection on practical experience" and that they seek to attract the broadest possible consensus.

\section{Organic Law 7/1998, of 5 October - Explanation of Reasons.}

This regulation reformed the Criminal Code by modifying the legal-criminal consequences of non-compliance with compulsory military service and alternative social benefits, claiming in its introductory text the existence of a "process already initiated for the full professionalization of the Armed Forces", insofar as "the sanctioning regulations must not be alien to the current historical moment".

\section{Organic Law 11/1999, of 23 No- vember - Explanation of Reasons.}

This text cites a series of documentary evidences as a basis for the modifications that this Law introduces in the crimes against sexual freedom: two proposals not of Law of the Popular Parlia- 
mentary Group of 26 November 1996 and of 6 May 1997, a Recommendation of the Ombudsman to the Ministry of Justice of 28 November 1997, the Resolution 1099 (1996), of 25 September, of the Parliamentary Assembly of the Council of Europe and the Joint Action of the Council of the European Union of 29 November 1996 concerning the fight against human trafficking and sexual exploitation of children.

It is on the basis of all these documentary references that the legislator then states that the current crimes against sexual freedom "do not adequately respond to the demands of national and international society" and to use as a legal basis for the protection of the dignity of the person Article 10 Spanish Constitution 1978 and Constitutional Court Rule n . 53/1985.

Furthermore, he argues that "the requirements of Spanish society, alarmed by the decrease in legal protection that has occurred in the area of crimes of sexual significance" since 1995, have motivated the reform. He adds that it has been foreseen, "following a notable example of comparative law", that in sexual crimes involving minors the calculation of the statute of limitations begins when the victim reaches the age of majority.

Finally, in justifying the reform of Article 23 of the Organic Law of the Judiciary to apply the principle of universality to the crimes of corruption of minors and incapacitated persons, it is stated that this is done by "considering them at the present time in history to be at least as important internationally as crimes relating to prostitution".

\section{Organic Law 14/1999, of 9 June - Explanation of Reasons.}

In this project, only the Action Plan against Domestic Violence approved by an Agreement of the Council of Ministers on 30 April 1998 is cited as documentary evidence, which included, among a series of measures, certain legislative reforms in the Criminal Code and in the Criminal Procedure Law "to achieve the eradication of criminal conduct consisting of ill-treatment, while at the same time providing greater and better protection to the victims of such deplorable behaviour".

\section{Organic Law $2 / 2000$, of 7 January - Explanation of Reasons.}

Here the Paris Convention of 13 January 1993 on the prohibition of the development, production, stockpiling and use of chemical weapons and on their destruction is cited as documentary evidence.

\section{Organic Law 3/2000, of 11 January - Explanation of Reasons.}

The documentary evidence on which this project is based is the Convention of the Organization for Economic Cooperation and Development of 17 December 1997, for the fight against corruption of foreign public agents in international economic transactions, with the legislator merely noting that such corruption is a "phenomenon" present in "increasingly frequent and intense international commercial transactions".

\section{Organic Law $3 / 2000$, of 11 January - Explanation of Reasons.}

We do not know why this Organic Law is the only one that uses the label "Introduction" for its introductory text instead of the Statement of Purpose or Preamble. In any case, it is focused on introducing a series of legal-criminal reforms with respect to the crimes of terrorism.

The legislator states at the outset that "terrorist behaviour evolves and seeks to evade the application of the rules by taking advantage of 
the loopholes and complexities of interpretation", so that it is necessary to "provide an effective response to these needs from the legal system, through the ordinary instruments that our Constitution admits and demands".

In particular, when speaking of "urban terrorism", it is stated that "experience shows" that the provisions of the current Article 577 "are not fulfilling the objective pursued" for two reasons: "On the one hand, because events of urban terrorism are only considered as such in the case of risk to the life or physical integrity of persons. On the other hand, because current legislation does not make it easy to condemn those who take part in these actions who carry, not the explosives or weapons that cause fire or destruction, but only the components necessary to cause the explosion". The precept is therefore reformed to allow for these conducts on the basis that "they are not limited to damaging individual or collective material goods, but seek to terrorise an entire population or collective in order to further terrorist aims".

Furthermore, the introduction of a new Article 578 is justified to punish those who either extol or justify by any means terrorist acts or their perpetrators, or those who humiliate the victims or their relatives, because these are "acts all of which produce perplexity and indignation in society and which deserve a clear criminal reproach".

\section{Organic Law 3/2000, of 11 January - Explanation of Reasons.}

As a continuation of Organic Law 7/1998 and once the process of professionalization of the Armed Forces was completed, the Criminal Code was again reformed, as military service and alternative social benefits were suspended by virtue of two Royal Decrees cited as documentary evidence here by the legislator: 247/2001 of 9 March and 342/2001 of 4 April.

This "momentous change" was to be "immediately reflected in the criminal law", while introducing a transitional provision aimed at "reviewing the final sentences handed down in relation to the commission of the crimes decriminalised" through this rule.

\section{Organic Law 3/2000, of 11 January - Explanation of Reasons.}

This reform, on child abduction, was based on the will to "avoid, as far as possible, the harmful effects that certain actions of their parents may cause them in cases of family crisis". Furthermore, it is said that the reform has a clear point of contact with the reality on which these crimes are projected: it focuses on the cases in which the abductor is the parent who is not attributed the powers of custody of the child, while they are cases in which "it is necessary to provide a clear criminal response, other than the crime of generic disobedience.

\section{Organic Law $3 / 2000$, of 11 January - Explanation of Reasons.}

The introductory text of this Organic Law began by legally basing its content on the specification and development that the jurisprudence of the Constitutional Court had carried out to date on the principles of legality and criminal classification ex art. 9.3 of the Spanish Constitution 1978 and later indicated that the origin of the reform contained in this Law was found in the "proposals made by the Technical Commission for the study of the reform of the system of penalties".

A series of arguments were then used in this text, such as that "daily reality and experience show how in the enforcement of sentences the- 
re are broad areas of discretion, variable areas in which it is appropriate, according to the best doctrine, to establish rules to make a more accurate forecast of the sentence to be served".

It was also argued that "as authoritative criminal doctrine has pointed out, the greatest deterrent to crime is not the harshness of the penalties, but their infallibility, so that the certainty of a punishment, even a moderate one, will have more effect than the fear of a more severe one coupled with the hope of impunity or its breach", but also that "society demands more effective protection against the most serious crime standards [...], protection which the rule of law not only can but must provide". That is why it decided to "prevent" flexibility in the serving of sentences and prison benefits (despite recognising their raison d'être in the aim of reintegrating criminals in accordance with the Spanish Constitution) "from becoming mere instruments at the service of terrorists and the most serious criminals to achieve a quite different end". In fact, it was later stated categorically that, 'in practice, the rules which the Criminal Code established are being used precisely to infringe those principles [the general principles of criminal law], becoming instruments which terrorists use for their benefit in their constant violation of the rules and principles of the rule of law'".

When explaining the specific measures adopted to achieve these objectives, it was explained, for example, that the security period introduced by reference to "other European rights", and the extension of the maximum limit for effective completion of sentences to 40 years, was justified by the fact that "there are certain offences which, because of their special seriousness [in addition to the nature of the legal asset damaged, the recidivism of their perpetrators, etc.], require a more forceful response from the criminal law system".

\section{Organic Law 11/2003, of 29 Sep- tember - Explanation of Reasons.}

The scope of this reform covered citizen security, domestic violence and the social integration of foreigners, so the documentary evidence cited by the legislator to justify it was the Government's Plan for the Fight against Crime of 12 September 2002, which aimed to "improve the protection of citizens' rights, particularly against criminal attacks", and the Treaty on European Union following the initiatives promoted by the European Council as a result of its meeting at Tampere.

This introduction also stated that "social reality has shown that one of the main problems to which the criminal law must respond is that of [...] professionalised crime", while "there are numerous examples of those who commit petty crimes on a large number of occasions, crimes which, due to their individualised amount, do not receive an adequate penal response".

That is why the "aggravating circumstance of recidivism, in this case qualified by the number of offences committed" is introduced, as it is said, "following a criterion already established in our doctrine and legal texts".

On the other hand, with regard to domestic violence, it is stated that the reform is intended to reach "all its manifestations and for its regulation to fulfil its objective in the preventive and repressive aspects".

Finally, regarding the phenomenon of illegal immigration, it is claimed that there is "accumulated experience in dealing with it" and it is stated that "illegal trafficking in persons [...] prevents the integration of foreigners in the country of destination". It adds precisely that, recognising that "with the social integration of foreigners in Spain new realities appear to which the legal system must provide an adequate response", the crime of female genital mutilation is also defined. 


\section{Organic Law $15 / 2003$, of 25 No- vember - Explanation of Reasons.}

This Organic Law begins by talking about the Criminal Code, making reference to the fact that "the time that has passed since [1995] has shown that it is necessary to update it in order to address new needs that have arisen from the experience gained with its application".

Next, he refers as basic evidence, firstly, to a Resolution of 1998 of the Congress "urging the General Council of the Judiciary to study the effective application of the Criminal Code, detecting the problems that it entails", a task that derived in a Report of the aforementioned body of 12 July 1999 including an "analysis of those aspects that have posed greater complexity in the application of the new Code".

Secondly, mention is made of the Technical Commission for the reform of the system of penalties within the Ministry of Justice, already referred to in the Draft Organic Law 7/2003, which carried out a "study" that "bases many of the reforms of the articles of the Criminal Code contained in this Organic Law".

And thirdly, alongside this Technical Commission proposal, which refers "essentially" to the "system of penalties and its application", consideration is given to "various parliamentary proposals" and "in accordance with the most pressing social concerns" to "adapt" the "existing types" and introduce "new forms of crime" and thus, it is stated, "ensure that the criminal law provides an effective response to the current reality of crime".

When we go into the review of the normative novelties that are exposed for each of the criminal groups affected by the reform, we find evidence references only in the following four cases:

In the crimes of slander and libel against a public official or administrative authority or agent thereof, it is said that it has been established "in accordance with an important sector of doctrine" that they can be prosecuted ex officio.

In crimes against intellectual and industrial property, the penalty is increased and their classification is technically improved "in accordance with social reality [...] and their impact on economic and social life".

- $\quad$ As for the new offences concerning access to radio or television broadcasting services or interactive services provided at a distance by electronic means, it is stated that these are intended to "respond to the criminal phenomena that have arisen around the phenomenon of the massive incorporation of information and communication technologies into all sectors of society".

Finally, with regard to environmental crimes, it is said that their reform is being addressed because they are especially protected legal assets "and the subject of growing social concern".

\section{Organic Law 20/2003, of 23 De- cember - Nothing.}

This Organic Law contained absolutely no introductory text and, of course, no supposed empirical evidence, its aim being simply to reform the Criminal Code to punish the illegal calling of referendums (by adding three new precepts) in response to the "Ibarretxe Plan", which was a political document containing a roadmap aimed at achieving the independence of the Basque Country.

\section{Organic Law $1 / 2004$, of 28 De- cember - Statement of Reasons.}

Thematically aimed at pursuing gender-based violence, the introductory text of this Organic Law, the first reform undertaken by the new 
government resulting from the general elections of 14 March 2004, contained various evaluative passages which we will not quote as they simply configure a political-ideological discourse without any empirical pretensions.

However, Articles 9.2 and 15 of the Constitution, the IV World Conference of the United Nations in 1995 and a long list of other international legal texts were also cited as normative references for the reform: the Convention on the Elimination of All Forms of Discrimination against Women of 1979; the United Nations Declaration on the Elimination of Violence against Women, proclaimed in December 1993 by the General Assembly; the resolutions of the last International Women's Summit held in Beijing in September 1995; Resolution WHA49.25 of the World Health Assembly declaring violence a priority public health problem proclaimed in 1996 by the WHO; the report of the European Parliament of July 1997; the Resolution of the UN Commission on Human Rights of 1997; and the Declaration of 1999 as the European Year for Combating Violence against Women, among others. These included the recent Decision No. 80/2004EC of the European Parliament adopting a programme of Community action (2004-2008) to prevent and combat violence against children, young people and women and to protect victims and groups at risk (Daphne II programme), while setting out the position and strategy of the representatives of the Union's citizens in this respect.

As far as we are concerned, the legislator stated that "in the Spanish reality, aggressions against women have a special incidence, and there is greater awareness today than in previous times, thanks in good measure to the efforts made by women's organisations in their fight against all forms of gender violence. It is no longer an "invisible crime", but one which produces a collective rejection and evident social alarm".

When referring to the measures of a criminal nature, contained in its Title IV, the legislator stated that "for citizens, for groups of women and specifically for those who suffer this type of aggression, the law wants to give a firm and conclusive response and show firmness by expressing them in specific types of criminal law".

\section{Organic Law 2/2005, of 22 June - Explanation of Reasons.}

The second reform of the new government was rightly aimed at repealing the novelties introduced by the last criminal reform of the previous Executive by means of Organic Law 20/2003. Here at least two arguments were offered with respect to the crimes of illegally calling referenda: it was said that these were "behaviours that are not sufficiently serious to warrant criminal prosecution, and even less so if the penalty envisaged by the law is prison" and that, in short, they "do not present the required marks to proceed to incrimination"

\section{Organic Law 4/2005, of 10 Oc- tober - Explanation of Reasons.}

This reform was undertaken with the aim of "strengthening punitive action in an area that could be improved", such as hazardous crimes caused by explosives. In this respect, the draft states that "the administrative sanctioning power is insufficient to stop the conduct of those who are obliged to do so and do not observe the measures of surveillance and control of the explosives". And that is why "certain infringements are introduced which, in practice, clearly prevent effective control of explosives, such as obstructing the inspection activity of the Administration, falsifying or concealing relevant information in the field of security measures and expressly disobeying the Administration's orders to rectify im- 
portant defects reported in security matters", in a clear reference to aspects that were highlighted during the criminal proceedings that took place in relation to the terrorist attacks of 11 March in Madrid.

\section{Organic Law 7/2006, of 22 No- vember - Explanation of Reasons.}

Specifically focused on the protection of health and the fight against doping in sport, this Organic Law sought to introduce a new offence against public health (art. 361 bis) into the criminal law in order to ensure compliance with all the measures provided for in the regulation. It stated that "with the establishment of this new criminal offence, the comprehensive design of a criminal policy against doping, initiated in February 2005 when the Council of Ministers gave the green light to the implementation of a Comprehensive Action Plan against Doping in Sport, is completed" consisting of fifty-nine measures.

\section{Organic Law 13/2007, of 19 No- vember - Explanation of Reasons.}

With the objective of extraterritorially prosecuting illegal trafficking and clandestine immigration of persons, this regulation was enacted with a brief introductory text, which, apart from modifying the Organic Law of the Judiciary, projected on articles 318 bis and 313.1 of the Criminal Code to punish illegal trafficking or clandestine immigration of persons or workers when the destination is any other country of the European Union, in view of the fact that "it is certainly difficult to give the necessary dignified treatment to immigrants and fully protect their human rights, in view of the overwhelming migratory flow in our country. A flow that comes, to a large extent, from the notable increase in the activities of organised cri- minal groups in relation to the illegal trafficking of immigrants, which every day puts their lives and safety at risk".

And this was to be solved on the basis of the United Nations Convention against Transnational Organized Crime, made in New York on 15 November 2000, supplemented by the Protocol, made at the same place and date, against the Smuggling of Migrants by Land, Sea and Air.

The aim was thus to resolve any doubts as to the interpretation of the law in favour of Spanish jurisdiction when a vessel (such as "patera" or "cayucos") was "rescued outside the territorial sea by a Spanish vessel [...] before reaching the Spanish coast".

\section{Organic Law $15 / 2007$, of 30 No- vember - Preamble.}

Here the term "Preamble" is used for the first time to refer to the introductory and explanatory section of the reasons for the penal reform, a constant that will be repeated from now on until the most recent penal reforms.

This Organic Law deals with crimes against road safety and takes as a reference the "resolutions approved as a result of the 2006 State of the Nation Debate" and, specifically, "number 19 " for the promotion by Congress of an amendment to the Criminal Code which would take into account "the various proposals being studied in the Road Safety Commission" in order to "define more rigorously all crimes against traffic safety and those related to road safety, preventing certain conducts qualified as road violence from going unpunished".

Thus, it is stated by the legislator that this reform "has a broad consensus of the parliamentary groups on the proposals made before the Commission on Road Safety" in Congress and that, specifically, the new offence of driving wi- 
thout a licence comes in response to "a criticised absence" of this offence in the Criminal Code until that time.

\section{Organic Law 5/2010, of 22 June - Preamble.}

As a starting point for this extensive, profound and important reform, it is stated that "the social evolution of an advanced democratic system such as the one configured by the Spanish Constitution determines that the legal system is subject to a constant process of revision". Thus, it is explained that "in this context, the present reform is framed within the confluence of several coordinates that explain both its relative extension and the variety of issues it addresses". These guidelines are essentially the following four:

- Spain's “international obligations", "especially in the area of European legal harmonisation", which "require adaptations -sometimes of considerable significance- to our criminal law".

- The "experience of applying the Code", which "has highlighted some shortcomings or deviations that need to be addressed.

Thirdly, "the changing social reality determines the emergence of new issues to be addressed".

And finally, "the numerous and sometimes accelerated changes made to the original architecture of the 1995 text have produced some distortion or inconsistency effects that need to be corrected".

The first matter in which some reference is made to evidence taken as a basis for the amendment of the Criminal Code is that of circumstances modifying criminal liability, by expressly including in the articles the extenuating circumstance of undue delay, taking into account, in doing so, "the fundamental elements of the jurisprudence of the Supreme Court, which has constructed this circumstance as extenuating by analogy".

It goes on to warn, in announcing the regulation of probation, that 'it is well known [...] that in certain particularly serious cases the rehabilitative effect of the sentence is made more difficult, in so far as the sentence is not sufficient or adequate to exclude a high risk of recidivism'. It is therefore considered that 'once the retributive dimension of the sentence has been exhausted, the continued dangerousness of the subject finds its appropriate response in a security measure', the probation measure referred to above.

He then justifies the greater role of the permanent localisation penalty "in this line of evolution of the legal-criminal response towards more operative formulas that are better adapted to current social needs and demands", adding that, in the cases in which it is envisaged as the main penalty, "it may be the appropriate instrument to combat more rigorously and effectively the cases of repeated offences that have generated special citizen insecurity in recent times", although restricting its application to repeated offences of theft, using two reasons drawn from reality for this: "On the one hand, it is the assumption that, above all in the most important urban centres, it has generated the greatest public concern and is the one that today really requires the adoption of this measure. On the other hand, the restriction of this type of permanent location to a specific case will allow the resources available in the prison system to be properly used".

When justifying the new criminal liability of legal persons, it is explained that "there are numerous international legal instruments that demand a clear criminal response" for them, "above all in those criminal figures where their possible intervention is most evident (corruption in the private sector, in international commercial transactions, pornography and child prostitution, trafficking in human beings, money laundering, illegal immi- 
gration, attacks on computer systems...)". It adds that "the system clearly prevailing in comparative law and in the Community texts to be transposed is chosen here, whereby the fine is the common and general penalty for all cases of liability, with the additional imposition of more severe measures being reserved for qualified cases only [...]".

The legislator then notes that "of particular importance is the transposition of Council Framework Decision 2005/212/JHA of 24 February 2005 on Confiscation of Crime-Related Proceeds, Instrumentalities and Property", by virtue of which "the existing rules on confiscation have been supplemented" in the terms of the "Council Framework Decision 2002/475/JHA on combating terrorism".

In the area of statutes of limitation, it is argued that "with the aim of increasing legal certainty, a detailed regulation of the institute has been chosen to put an end to the differences in interpretation that have arisen in recent times". Specifically, it refers to "the impunity due to the prescription of certain crimes punished with penalties that are not excessively serious (fraud, urban planning crimes, for example, or some crimes against the public administration), whose discovery and investigation can however be extremely complex and lengthy", which "has resulted in discrediting the judicial system and directly harming the victims", in the face of which the legislator decided to raise the minimum prescription period for crimes from three to five years, in the case of those that had foreseen a prison sentence or disqualification of less than three years.

Subsequently, reference is made to the fact that, "in response to the increasingly widespread phenomenon of the purchase and sale of human organs and the call from various international forums to address their punishment", the illegal obtaining of or trafficking in human organs, as well as their transplantation, is now expressly typified.
In this respect it is recalled that "as early as 2004 the World Health Organisation declared that the sale of organs was contrary to the Universal Declaration of Human Rights", and that "at the International Summit on Organ Transplant Tourism and Trafficking held in May 2008, representatives of 78 countries agreed on the so-called 'Istanbul Declaration', which states that such practices violate the principles of equality, justice and respect for human dignity, and must be eradicated".

It goes on to explain that, "in line with the proliferation, over the last decade, of harassing behaviour in the housing sphere", real estate harassment is now expressly classified, in order to protect the right to the enjoyment of housing by owners or tenants against attacks inspired, "in most cases", by "speculative targets". This affirmation is based on "different judicial pronouncements that have shown the difficulties in repressing these conducts due to the absence of a specific criminal regulation of this phenomenon".

Furthermore, it is explained that "the unified criminal treatment of the offences of trafficking in human beings and illegal immigration contained in Article 318 bis was clearly inadequate, in view of the great differences between the two criminal phenomena". Thus, "the separation of the regulation of these two realities is essential both to comply with the mandates of international commitments and to put an end to the constant conflicts of interpretation".

The reform carried out in the field of sexual offences is essentially based on "the need to transpose Council Framework Decision 2004/68/ JHA of 22 December 2003 on combating the sexual exploitation of children and child pornography".

That of computer-related crime, in the same sense, "to comply with Framework Decision 2005/222/JHA of 24 February 2005 on attacks against information systems". 
With regard to frauds, it is said that "it has been necessary to incorporate the increasingly widespread modality consisting of defrauding by using other people's cards or the data on them, thereby carrying out operations of any kind to the detriment of the holder or a third party", adding that the system of qualifications or specific aggravating factors of this group of crimes "has been posing problems of interpretation in practice, This, according to the legislator, was "particularly evident" when it came to the use of cheques, promissory notes, blank bills of exchange or fictitious exchange transactions which, being at the same time instruments and materialisation of the fraud, "their separate valuation is unnecessary".

Later on, it is stated that the criminal aggravation operated by the Organic Law 15/2003 for crimes against intellectual and industrial property "has shown a certain failure of the necessary proportionality of the penalty in the case of conducts consisting of the small-scale sale of fraudulent copies of works protected by such rights, especially as the perpetrators of this type of behaviour are often people in situations of poverty, sometimes used by criminal organisations, who seek to achieve a minimum subsistence income through such acts", which is why a more lenient penalty is envisaged for these cases.

It also notes that the reforms implemented in market and consumer-related offences have "as their reference Council Directive 2003/06 of 28 January 2003 on insider dealing and market manipulation".

Likewise, the new offences for the repression of corruption in the private sector have their raison d'être in "the transposition of Framework Decision 2003/568/JHA", specifically approved for this purpose within the European Union.

When explaining the reform of land use and urban planning offences, it is stated that "the scope of typical conduct is extended to illegal or clan- destine urbanisation works" because "they can have a greater impact on the territory than mere construction or building works, which moreover often precede them". Furthermore, the concealment of illicit acts observed by the inspection and the omission of inspections that are obligatory, "as demanded by the doctrine", are now expressly typified.

The changes to environmental offences (essentially the increase in their penalties) also stem from "the need to take on board elements of harmonised European Union legislation in this field", thus incorporating "the cases provided for in Directive 2008/99/EC of 19 November" in this area.

In explaining the reform of the offence of animal abuse in Article 337, it is said that the removal of the requirement of overkill "made the application of the precept considerably more difficult".

With regard to drug trafficking, some adjustments in penalties are announced "in accordance with international standards, in particular Council Framework Decision 2004/757/JHA of 25 October 2004 laying down minimum provisions on the constituent elements of criminal acts and penalties in the field of illicit drug trafficking". It adds that it also "welcomes the provision contained in the Agreement of the Non-Jurisdictional Plenary Session of the Second Chamber of the Supreme Court of 25 October 2005 regarding the possibility of reducing the sentence" in certain cases. In addition, "some problems of interpretation" had been detected when applying the aggravating circumstance of a ship, in view of which the term "ship" was added to the articles, with the aim of "allowing the inclusion of other types of vessels commonly used in these offences, such as semi-rigid ones".

With regard to the falsification of certificates, it is explained that "the falsification of identity documents [...] has become an intolerably widespread practice" and that "for easily unders- 
tandable reasons, criminal intervention extends to trafficking in false identity documents, as well as to the same conduct carried out in relation to identity documents belonging to another State of the European Union or a third State if the aim is to use them in Spain".

On the other hand, the express criminalisation of the counterfeiting of credit or debit cards, or of travellers' cheques, has its reason for being in "the proven frequency with which these criminal activities are discovered as belonging to criminal organisations".

It goes on to say that the amendments made to the bribery offences were intended "to bring our legislation into line with the international commitments entered into, in particular the Council of Europe Criminal Law Convention on Corruption of 27 January 1999 and the Convention drawn up on the basis of Article k.3(2)(c) of the Treaty on European Union, on the fight against acts of corruption involving officials of the European Communities or officials of Member States of the European Union". Furthermore, a specific case is dealt with, such as that of the crime of corruption of foreign public officials in international commercial transactions, which had been introduced into the Criminal Code by Organic Laws 3/2000 and 15/2003 "in compliance", as explained above, "with the Organisation for Economic Co-operation and Development (OECD) Convention on Combating Bribery of Foreign Public Officials in International Business Transactions". It is now a question of remedying the "deficiencies" in this type of criminal law, insofar as "they demand a new reform which will definitively bring our national law into line with the terms of the Convention".

It goes on to explain that the offence of unlawful association is modified in the light of 'the development of case-law' which 'has demonstrated' its 'inability [...] to respond adequately to the various scenarios of criminal groups or orga- nisations'. In particular, it is mentioned that it is "poorly applied", that "criminal organisations and groups in general are not really "associations" that commit crimes", or the fact that "Article 515 of the Criminal Code had generated problems in the field of international cooperation because of the problems that the qualification of the terrorist organisation as an illicit association entailed for the fulfilment of the requirement of double criminality". Furthermore, it is stated that "knowing precisely the doctrinal controversy that has arisen around the systematic placement of these types of crimes", it has been decided to place them in the framework of crimes against public order, assuming that they are such "unequivocally, if one takes into account that the phenomenon of organized crime directly attacks the very basis of democracy [...]". Finally, it is recalled that "the jurisprudence concerning the crime of illicit association [...] requires the verification of a structure with a vocation of permanence, leaving out other similar phenomena very widespread in today's society, sometimes extremely dangerous or violent, which do not meet these structural requirements". Thus, it is stated that "the need to respond to this reality leads to the definition, in parallel with the organisations, of what this Law calls criminal groups", in the new Article 570 ter.

The first to last point is that the reorganisation and clarification of the criminal treatment of terrorist conduct stems from the need to comply with the "legislative obligations arising from Framework Decision 2008/919/JHA", furthermore taking into consideration "the particular way in which certain relatively recently developed terrorist groups or cells operate on the international scene, whose degree of autonomy is precisely an added factor that makes it difficult to identify and dismantle them". It also explains that the conduct of distributing or publicly disseminating messages or slogans on this matter by any means is 
now classified as a crime insofar as "it has been proven that it is undeniably suitable for generating the breeding ground on which, at a given moment, the executive decision to commit a crime matures, although, as required by the Framework Decision and the Council of Europe Convention on terrorism, such conduct must generate or increase a certain risk of committing a terrorist offence".

The penultimate section states that the reform of crimes against the international community is being undertaken on the basis of the rules implementing the Rome Statute of the International Criminal Court and the ratification by Spain of other instruments of international humanitarian law, among which the most important are the Convention of 18 September 1997 (Ottawa Treaty) on the prohibition of the use, stockpiling, production and transfer of anti-personnel mines and on their destruction, the Convention on the safety of United Nations and associated personnel of 9 December 1994, the Second Protocol of 26 March 1999 to the Hague Convention of 1954 on the protection of cultural property in the event of armed conflict and the Optional Protocol of 25 May 2000 to the Convention of 1989 on the rights of the child on the involvement of children in armed conflict. Furthermore, in the same vein, the creation of a new offence of piracy in this section of the Criminal Code is justified by the "need to respond to the problem of possible illegal acts against the safety of maritime and air navigation", complying for this purpose with "the postulates of the Montego Bay Convention of 10 December 1982 on the Law of the Sea and the Convention on Maritime Navigation signed in Rome on 10 March 1988".

Finally, an amendment to the Criminal Code is introduced to provide for specific civil protection of the rights of crime victims on the following grounds: "Not infrequently, in recent times, the media have accessed the programming of those who have committed criminal offences and have been convicted by final judgement, and have even boasted of the criminal behaviour they have perpetrated, disseminating manifestly false information about it and also obtaining unjustifiable economic gain", attacking such behaviour "against the dignity of those who have suffered the consequences of these acts and their loved ones, who are subjected to a new traumatic experience derived from this public invasion of their honour and privacy".

\section{Organic Law 5/2010, of 22 June - Preamble.}

In the Preamble of this regulation, created to modify the Organic Law on the General Electoral System, no reference is even made to the criminal law contained in its Second Final Provision, since it is merely a correction of four formal errors in the text of the immediately preceding reform.

\section{Organic Law 7/2012, of 27 De- cember - Preamble.}

Once again, the argument is used here that the content of the Criminal Code "must be adjusted to the changes and new needs of the current situation".

The reform in question is structured according to three criteria, within which arguments based on more or less solid "evidence" are brought up:

- The first of these is the reinforcement of the transparency of the activity of the administration and the system of responsibility of political parties and trade unions, in respect of which it is stated that with the modifications introduced in the system of criminal responsibility of legal persons "the perception of impunity of these two actors in political life that was transferred by the 
previous regulation is overcome".

The second is to improve the effectiveness of instruments for monitoring public revenue and expenditure, within which two modifications are undertaken for which "evidence-based" arguments are cited: With regard to the new configuration of tax regularisation, it is stated that it establishes a relationship of equivalence with the timely payment of the tax, "as both the General State Prosecutor's Office and the Supreme Court have stressed"; secondly, with regard to the reduction of the amount defrauded in crimes against Social Security to fifty thousand euros, it is explained that "the current social and economic reality highlights the need to act, with greater force, against alleged criminal behaviour and organised schemes which endanger the financial sustainability of the Social Security System", so that the measure adopted "makes it possible to make punishable by criminal law acts which are currently only punishable by administrative penalties and which are the subject of strong social reproach at times of particular economic difficulty in the business world such as the present". In this point the legislator adds that "in practice there are cases in which it is interpreted that there is no crime against Social Security simply because the contribution documents have been presented, without assessing whether they are true and complete", so that a clause is added that prevents this interpretation from continuing to be applied by our Courts and Tribunals.

The third and final guiding criterion of the reform concerns a set of measures adopted in respect of economic activities where there is a greater perception of fraud. Thus, when explaining the reform of the offence against workers' rights in article 311, the legislator states that there are those who collectively "are failing to comply with their obligations in relation to compulsory insurance, or with regard to the compulsory au- thorisations to work of those they employ in their business activity". That is why he justifies that "those who, in a massive or collective way, resort to the use of workers without having formalised their incorporation into the corresponding Social Security System, or without having obtained the obligatory authorisation to work in the case of foreigners who need it, should deserve the corresponding criminal accusation", finishing his speech by stating that "the damages caused by these behaviours are evident", highlighting mainly two: the denial of workers' social security rights and the fact that those who produce goods and services at much lower labour costs are defrauding, as opposed to those who have to bear their obligations in this area.

The remaining changes are explained on the basis of hypothetical assumptions. For example, with regard to the classification of the "falsification of information of economic importance which does not initially form part of a document, but which is subsequently reflected in it", the legislator argues that this "solves the problems of typification which may arise when the author does not issue the false document, but merely introduces the mendacious information which is then incorporated into a written documentary or other support".

\section{Organic Law $1 / 2015$, of 30 March - Preamble.}

This reform begins again by warning that through it the current Criminal Code "is subject to a complete revision and updating, in the awareness that the passing of time and the new social demands show the need to carry out certain modifications to our penal norm". And he adds a little further on that "the need to strengthen confidence in the Administration of Justice makes it necessary to put at its disposal a legal system that 
guarantees predictable judicial decisions that, furthermore, are perceived in society as fair".

We will begin by outlining the evidence used by the legislator when explaining each of the reforms undertaken in particular, and will start by referring to the fact that revisable permanent detention corresponds to "an extended model in European comparative law that the European Court of Human Rights has considered to be in line with the European Convention on Human Rights", expressly citing the case law of this Court in this regard; and adds that "the Council of State has also had the opportunity to pronounce on the constitutionality of indeterminate -but revisablesentences, when reporting on Spain's ratification of the Statute of the International Criminal Court, which provides for the possible imposition of a permanent prison sentence".

With regard to the technical improvement of the criminal liability regime for legal persons created in 2010, it is said that "it puts an end to the interpretative doubts that had been raised by the previous regulation, which from some sectors had been interpreted as a regime of vicarious liability, and it assumes certain recommendations that had been made by some international organisations in this regard", without expressly mentioning which ones, although we know that they essentially originated in the Group of States against Corruption (GRECO) of the Council of Europe, to which we will refer again later.

With regard to the modification of the regime of suspension of the execution of the sentence, it is explained that "experience had shown that the existence of a criminal record did not justify in all cases the refusal of the suspension", so that “it was therefore preferable to introduce a regime that would allow judges and courts to assess whether the criminal record of the convicted person is, by its nature and circumstances, relevant to evaluate its possible dangerousness [...]". In addition, it is valued that, at the same time, "the current situation in which the existence of a triple regulation of the suspension (ordinary suspension, suspension in the case of drug-dependent offenders and substitution of the sentence) gives rise, on many occasions, to three successive decisions that are the object of repeated appeals" is put to an end, all of which "should result in greater speed and efficiency in the execution of sentences".

It goes on to say that "for the same purpose", the system for assessing compliance with civil liability is being reformed, since "the current system of prior verification is ineffective and not very flexible, and makes it difficult for decisions on suspension of the sentence to be taken at the same time as the sentence is passed".

As for the express equivalence of Spanish criminal records to those of convictions imposed by courts in other European Union Member States, the European reference standards for introducing this reform are cited as Framework Decision 2008/675/JHA, Decision 2008/315/JHA and Council Decision 2009/316/JHA, of 6 April 2009, which "highlight the need to simplify the procedure for clearing criminal records".

With regard to the reform of confiscation, apart from ensuring that European Directive 2014/42/EU, of 3 April, is taken into consideration, it is stated that "on many occasions, the assets and effects of criminal activities are transferred by their authors to third parties", which is why "the reform introduces some technical improvements aimed at increasing the effectiveness and legal certainty in the application of this regulation".

The Council of Europe Convention on the Protection of Children against Sexual Exploitation and Sexual Abuse, done at Lanzarote on 25 October 2007, ratified by Spain on 22 July 2010, and the case law of the European Court of Human Rights are cited to justify the inclusion of convicted 
persons' profiles in the DNA database.

The amendments to the offences against sexual freedom are justified on the occasion of the transposition of Directive 2011/93/EU on combating the sexual abuse and sexual exploitation of children and child pornography, which replaces Council Framework Decision 2004/68/JHA, apart from the 1989 UN Convention on the Rights of the Child and the Charter of Fundamental Rights of the European Union.

The modification of the provision of Article 187 regarding crimes of prostitution is justified "with the aim of more effectively prosecuting those who profit from the exploitation of the prostitution of others", adding as a reinforcement of the argument "that the jurisprudence of the Supreme Court had demanded some requirements for the assessment of the exigency of this situation similar to those applied in the field of regulated labour activities, which made it impossible in practice to prosecute them".

Furthermore, as regards the inclusion of a new section to sanction those who knowingly access child pornography through information and communication technologies, it is stated that this has its reason to be "in the awareness that new technologies are a main way of accessing pornography supports".

To conclude with crimes related to sexuality, Article 183 ter is reformed to punish those who, through technological means, contact a minor under sixteen years of age and carry out acts aimed at tricking them into providing pornographic material or showing them pornographic images, with the legislator basing this on "the ease of access and anonymity provided" by the Internet or other means of telecommunication.

On another subject, the modification of the crimes against privacy finds an explanation in the desire to "solve the problems of the lack of criminalisation of certain types of behaviour", adding that the transposition of Directive 2013/40/EU, of 12 August, on attacks against information systems and the interception of electronic data when it is not a question of personal communication, is also being carried out, concluding that "the proposed modifications are intended to overcome the limitations of the regulations in force in order to offer a response to computer crime in the sense of European regulations".

As regards the review of the regulation of crimes against property and heritage, it is said that the main objective is to "provide a response to the problems posed by multi-crime and serious crime". Thus, simply by way of example and among others, it is said to address, firstly, the "serious problem currently posed by crimes committed on agricultural or livestock farms that cause significant harm to their owners [through] infringements [...] in which it is difficult to adopt effective protective measures, This circumstance is used to commit these crimes, which cause their owners an extraordinarily high level of damage, much greater than that which corresponds to the mere valuation of the stolen products, and are the cause of a serious feeling of lack of protection and insecurity for those who suffer from them"; secondly, the resolution of the "serious problem generated by the theft of copper cable from public service and general interest networks"; or, thirdly, the aim is to resolve "the usual problem that arose in cases where alarm systems were deactivated from inside the site", among others.

The reform of the regulation of unfair administration is very important and the legislator describes it as "close to that which exists in the different European legislations" and explains that "reasons [...] for the systematic nature of this decision".

The technical review of punishable insolvency offences is said to be undertaken in the face of "the need to establish a clear separation between 
the conduct of hindering or frustrating execution, which has traditionally been understood as the offence of seizure of property, and the offences of insolvency or bankruptcy". It also includes "two new offences [...] common in comparative law", which are the concealment of property in judicial or administrative enforcement proceedings and the unauthorised use by the depositary of property seized by the authority.

With regard to crimes against intellectual property, a significant technical improvement in their classification is introduced "in accordance with social reality, the configuration of the types of crime and their impact on economic and social life are also subject to review in this reform, in order to provide adequate legal and criminal protection". It also expressly typifies conducts that violate intellectual property rights from which "serious harm is derived", listing them all below and avoiding their citation here.

When the legislator speaks of the crimes of illegal financing of political parties, he defends that with its creation "a criminal response is given to the need to define a specific criminal type for these criminal acts", since in the current legislation there was no specific and concrete crime in this area.

He goes into considerably more detail in justifying the reform of crimes against collective security, arguing that "forest fires continue to be one of the most important problems affecting our mountains. According to data from the Ministry of Agriculture, Food and the Environment, the most serious forest fires have an intentional cause, and in many cases cause significant damage to natural heritage and public or private property, or generate situations of danger to the physical integrity of people that can lead to the loss of life, in September 2009, the European Parliament adopted a resolution calling on the Member States to toughen up and apply criminal sanctions to criminal acts that damage the environment and to impose them in particular on those who start forest fires.

On the other hand, the reform of Article 637 is based on the fact that "until now it has included conduct that should be classified as a crime, and not as a simple misdemeanour", and then it goes on to say that "there is no doubt that it is necessary to protect the trust that certain symbols, uniforms or badges generate, and their improper use should be criminally sanctioned".

The reforms implemented in the area of gender-based violence find two "evidence-based" explanations: The incorporation of gender-based violence occurs "in accordance with Council of Europe Convention No. 210 on the Prevention and Combating of Violence against Women and Domestic Violence, adopted in Istanbul by the Committee of Ministers of the Council of Europe on 7 April 2011; and the inclusion among the crimes of breach of conduct tending to render ineffective telematic devices for controlling precautionary measures and penalties for distance in this area, is made on the basis of a reference to them "in Circular 6/2011, from the General State Prosecutor's Office, on criteria for the specialised action unit of the Public Prosecutor's Office in relation to violence against women".

When explaining the reform of public nuisance offences, apart from making reference to their "nineteenth-century origin", the legislator explains that their regulation "did not define the offence, but rather juxtaposed a series of punishable conducts", so that this "generated problems of typicality, in some cases, and bankruptcy in others", which the modifications introduced are intended to solve.

It is very briefly explained below that the reform of the crime of trafficking in human beings in the current Article 177 bis is being addressed in order to adapt it "to Directive 2011/36/EU of 
5 April 2011 on preventing and combating trafficking in human beings, and protecting victims, and replacing Council Framework Decision 2002/629/ JHA".

Similarly, the review of the regulation of illegal immigration offences in Article 318 bis is undertaken to bring them into line with Directive 2002/90/EC, Framework Decision 2002/946/JHA and Directive 2009/52/EC on minimum standards on sanctions and measures against employers of illegally staying third-country nationals.

The reform of the conduct of incitement to hatred and violence is based on a twofold reason: the restrictive interpretation of the crime of genocide in the Constitutional Court's Ruling 235/2007 of 7 November and the need to bring its regulation into line with Framework Decision 2008/913/ JHA.

It is ensured that the updating of the terms referring to persons with disabilities brings about the International Convention on the Rights of Persons with Disabilities, made in New York on 13 December 2006, which aims to prevent discriminatory conduct that may prevent these persons from enjoying their rights on an equal basis.

The classification of forced marriage has its reason for being in the fulfilment of "the international commitments made by Spain in relation to the prosecution of crimes against human rights": Directive 2011/36/EU of the European Parliament and of the Council of 5 April 2011, on preventing and combating trafficking in human beings and protecting victims, includes forced marriage among the conducts that can give rise to exploitation of persons and the United Nations Convention on the Elimination of All Forms of Discrimination against Women, ratified by Spain. It adds that this crime is "already regulated in other countries around us, such as France, Denmark, the United Kingdom, Germany and Norway".

In the penultimate place, with respect to the new criminal type of harassment, it is stated that "it is intended to provide a response to conduct of undoubted seriousness which, on many occasions, could not be classified as coercion or threats", dealing specifically with "all those cases in which without necessarily announcing explicitly or not the intention to cause any harm (threats) or the direct use of violence to restrict the freedom of the victim (coercion), repeated conduct occurs through which the victim's freedom and sense of security are seriously undermined, and the victim is subjected to constant persecution or surveillance, or other continuous acts of harassment".

And, finally, the legislator is differentially proficient in explaining the repeal of Book III, which contained the misdemeanours. It states that this reform seeks "to rationalise the use of the public service of justice, in order to reduce the high level of litigation which falls on the courts, with measures designed to promote an effective and swift judicial response to any disputes which may arise", without losing sight of the fact that "criminal law must be reserved for the resolution of particularly serious disputes". Furthermore, he explains that the amendment is endorsed by the Attorney General's Office, "which advocates that the current offences considered as misdemeanours should be left out of the Criminal Code because of their low seriousness", as well as by the General Council of the Judiciary, "which has recently proposed decriminalising certain behaviours classified as misdemeanours as an appropriate measure to reduce the high levels of litigation, which are particularly high in the criminal justice system".

\section{Organic Law 2/2015, of 30 March - Preamble.}

This reform, which complements the previous major reform, focused specifically on terrorist offences. And to justify it, the United Nations Se- 
curity Council Resolution 2178, adopted on 24 September 2014, and Resolution 1373 (2001), whereby all Member States must ensure the prosecution of any person who participates in the financing, planning, preparation or commission of terrorist acts or provides support for such acts, were cited at the outset.

And, in addition, the legislator valued that the conduct referred to in the aforementioned UN Resolution 2178 "constitutes the maximum exponent of the new threats that international terrorism poses to open societies and which seeks to put at risk the pillars on which the rule of law is based and the framework of coexistence of the world's democracies", it notes that "international Jihadist terrorism is characterised precisely by the incorporation of these new forms of aggression, consisting of new instruments of recruitment, training or indoctrination in hatred, to be used cruelly against all those who, in their extremist and violent ideology, are described as enemies". He concludes that "these new threats must therefore be combated with the most effective tool that democrats can use against the totalitarian fanaticism of terrorists: the law".

\section{Organic Law $1 / 2019$, of $20 \mathrm{Fe}-$ bruary - Preamble.}

This penultimate penal reform directly announces in its very title its purpose: "to transpose European Union directives in the financial and terrorist fields and to address issues of an international nature". In particular, the preamble explains that "several directives of a criminal nature need to be transposed without delay, either because of the expiry of the deadline or because of the proximity of that deadline": Directive 2014/57/EU of the European Parliament and of the Council of 16 April 2014 on criminal sanctions applicable to market abuse, Directive 2017/541/EU of the Euro- pean Parliament and of the Council of 15 March 2017 on combating terrorism and Directive (EU) 2017/1371 of the European Parliament and of the Council, of 5 July 2017 on combating fraud affecting the financial interests of the Union through criminal law, as well as completing the transposition of Directive 2014/62/EU of the European Parliament and of the Council of 15 May 2014 on the criminal law protection of the euro and other currencies against counterfeiting.

In addition, the regulation of the crime of trafficking in human organs is amended to bring it into line with the Council of Europe Convention on Action against Trafficking in Human Organs of 25 March 2015.

And, finally, as was the case with Organic Law $3 / 2000$, it is explained that this reform once again introduces modifications in the crimes of corruption, but this time it is expressly stated that it is done in order to follow the guidelines of the Group of States against Corruption (GRECO) of the Council of Europe.

\section{Organic Law 2/2019, of 1st March - Preamble.}

TFinally, in this last penal reform, which reforms the Criminal Code with regard to imprudence in driving motor vehicles or mopeds, as well as to sanction abandonment of the place of the accident, it is stated that "it responds to an important social demand, in view of the increase in accidents in which pedestrians and cyclists are affected by imprudence in driving motor vehicles or mopeds".

It specifies that the introduction of three cases of serious negligence, as well as an authentic interpretation of less serious negligence, means giving "legal status to the activity which the Public Prosecutor's Office and the courts have already agreed on, as is clear from Instruction 10/2011 of 
the Public Prosecutor's Office on road safety".

And he finishes the introductory explanation by stating that, with the introduction in the art. 382 bis of the new crime of abandonment of the scene of the accident, the intention is to punish, from a triple aspect, "the intrinsic evil in the abandonment of those who know that they are leaving behind someone who may be injured or even dead, the lack of solidarity with the victims, which is criminally relevant due to direct involvement in the accident prior to abandonment, and the legitimate expectations of pedestrians, cyclists or drivers of any motor vehicle or moped, to be attended to in the event of a car crash".

\section{CONCLUSIONS}

Taking stock of all the references that have been recapitulated here, we can draw a number of very simple and direct conclusions.

The first could be that the different legislators have argued to use quite a lot of evidence, but only in the sense of knowledge extracted from the observation of reality, in many cases without the slightest contrast. In any case, what is equally clear is that the cases in which such evidence could be considered authentic empirical evidence, or at least attempts to make it so, are absolutely exceptional and very rare.

The latter would be somehow related to the second conclusion: not everything that has been done throughout the Spanish criminal legislative process during the last twenty-five years is absolutely disposable. Specifically, the recourse to the Technical Commission for the study of the reform of the system of penalties can be considered as very positive and it is an experience that has been repeated once again throughout our criminal legislative history, with more or less transparency. In any event, this measure can be considered only as a first step towards a possible future model that is closer to others, much more complete, that have been proposed in recent years and to which I referred in another paper ${ }^{6}$.

Thirdly, it should be noted that the current legislative Preambles (previous Explanatory Memoranda) show a progressively growing imposition of supranational regulations, mainly by the European Union. Indeed, the legislator now makes very frequent references to the fact that this or that modification in one or another criminal group is undertaken due to the need to transpose Community regulations or to assume the provisions of this or that international convention, if not to attend to the relentless evaluation rounds of the aforementioned Group of States against Corruption within the Council of Europe.

Precisely, fourthly, it can be stated that references to documentary evidence are also very constant, mainly those already mentioned of an international normative nature, but also in some cases those which must be attached to any bill submitted to the Spanish Parliament in criminal matters in accordance with the Law on Government and its subsequent reforms (reports of the General Council of the Judiciary, the Council of State, the Attorney General's Office, etc.). To these are added, on many occasions, references to documentary evidence such as specific rulings of the Supreme Court or the Constitutional Court, some recommendation of the Ombudsman, agreements of the Council of Ministers, etc.

But, in short, is all this enough to be able to say that real empirical evidence has been used in the Spanish criminal legislative process over the last two and a half decades? Obviously, no, it is not. In fact, it could be asserted that authentic empirical evidence has never been used by the different criminal legislators in Spain, in the sense in which we have defined it at the beginning of this work, that is, as scientific evidence or information obtained from reality through the scientific 


\section{Samuel Rodríguez Fernández}

method, and, therefore, neutral, free of prejudice, bias or distortion, and suitable in short to allow the verification or refutation of their hypotheses. Apart from what has already been stated in the previous conclusions, it also happens that the different criminal legislators have quite frequently made references to information supposedly acquired through observation, but it is equally true that with the same frequency these were linked to perceptions that were not scientifically verifiable (for example, of the type "social reality has shown that one of the main problems to which the criminal law must respond is that of ..."). This is precisely one of the aspects to be avoided and inevitably eradicated from the legislative method of our State in the future. And perhaps the "Science in Parliament" 7 initiative can be used in this sense, as the Spanish Group for Criminal Legislative Policy is trying to do. And perhaps a first step along this new path would be to draw up a protocol on how to use real scientific evidence in the criminal legislative process, as we intend to do through the NEXO research project. It is in this line that we want to continue working persistently to improve our criminal legislative procedure as much as possible.

\footnotetext{
${ }^{6}$ RODRÍGUEZ FERRÁNDEZ, S., La evaluación de las normas penales, Dykinson, Madrid, 2016.

${ }^{7}$ Defined on its own website https://cienciaenelparlamento.org/ as "an independent citizen's initiative that aims to make science and scientific knowledge one of the sources of information in the formulation of policy proposals".
} 